\title{
Assessing Production Potential of Wheat Crop (Var; Kanchan) in Raipur District of Chhattisgarh Region under Projected Climate Scenarios
}

\author{
M.K. Beck ${ }^{1 *}$, A. Jain ${ }^{1}$ and S. Mohanty ${ }^{2}$ \\ ${ }^{1}$ Department of Agrometeorology, Indira Gandhi Krishi Vishwavidyalaya, Raipur-492012, India \\ ${ }^{2}$ Department of Agricultural Meteorology, College of Agriculture Bhubaneswar, OUAT, India \\ *Corresponding author
}

\section{A B S T R A C T}

\begin{tabular}{|l|} 
Ke y w o r d s \\
Simulation, \\
CERES-model, \\
$\begin{array}{l}\text { Wheat crop, } \\
\text { Projection scenario, } \\
\text { Yield. }\end{array}$ \\
\hline Article Info \\
\hline $\begin{array}{l}\text { Accepted: } \\
19 \text { October } 2017 \\
\text { Available Online: } \\
10 \text { December } 2017\end{array}$ \\
\hline
\end{tabular}

Crop simulation model (CERES - wheat model) was used to simulate and assessing wheat variety of Kanchan at Raipur district of Chhattisgarh. In this context, during the year 2013-14 experiments on three sowing dates viz. Nov. 25(D1), Dec. 05(D2) and Dec. 10(D3) were conducted at Department Agrometeorology, IGKV, Raipur. Results revealed that the model outputs were three dates overall maximum production found in 2050's at projected scenarios. Maximum observed values with $25^{\text {Th }}$ November sown crop than other sowings of crop in terms of phenological events, biomass accumulation and grain yields. However, under projected years (2030, 2040 and 2050) decreases the yield with increasing year. These results indicate that CERES-Wheat model can be used as a tool to support decision-making for wheat production in different three dates of sowing.

\section{Introduction}

Since agricultural production is greatly affected by climate, any changes in climate which may result from increasing concentrations of greenhouse gases in the atmosphere could have serious consequences for agricultural yield potential (Mearns, 2000). Food and energy security of India are crucially dependent on favourable weather. According to the estimates by IPCC (2007) earth's linearly averaged surface temperature has increased by $0.74^{\circ} \mathrm{C}$ during the period 1901-2005. Crop growth simulation models, combining knowledge of crop characteristics and their interactions with the environmental variables have been developed for calculating yield levels of crops under well specified conditions. Simulation studies are useful in predicting future climate scenario based on changing trends in temperature, $\mathrm{CO}_{2}$ and rainfall etc (Haris et al., 2010b; Haris et al., 2012). Wheat is sensitive to high temperature (during early and late stages of the crop) but magnitude of damage depends on the variations of ambient temperature, stage of development and varieties (Asseng et al., 2011; Modarresi et al., 2010). Predicted increase in temperature for future time periods may prove to be detrimental in future time periods for rabi crops, however, crop like winter maize may be benefitted due to 
increase in temperature upto some extent (Chhabra and Haris, 2014).

The Inter-Governmental Panel on Climate Change (IPCC, 2007) made future projections and reported that crop production loss in India by $2100 \mathrm{AD}$ could be $10-40$ per cent despite the beneficial effects of higher $\mathrm{CO} 2$ on crop growth. We could lose 4-5 million tonnes of wheat (Triticum aestivum) with every rise of $1^{\circ} \mathrm{C}$ temperature. The decrease in radiation and increase in minimum temperature were responsible for the yield decline. In the same way, Sastri (2010) was worked out on crop simulation models and found that an increase of temperature by $1^{\circ} \mathrm{C}$ at reproductive stage could reduce the potential yield of rice from $9.35 \mathrm{t} /$ ha to $8.89 \mathrm{t} / \mathrm{ha}$ under irrigated condition and from $8.93 \mathrm{t} / \mathrm{ha}$ to $8.43 \mathrm{t} / \mathrm{ha}$ under rainfed conditions in Chhattisgarh state.

In this study the effects of projected temperature change in changing climatic scenarios on the production potential of wheat in Chhattisgarh regions have been analysed using DSSAT model (Version 4.6). Simulation studies are carried out with three dates of sowing for wheat to get the ideal planting window in future temperature scenarios of Chhattisgarh regions.

\section{Materials and Methods}

For this study, Raipur district in Chhattisgarh regions are selected (Table 1), representing district, on the basis of availability of meteorological, soil and crop data.

Daily data for air temperature and rainfall from Raipur station representative of each collected for the period 1971-2014. Missing values of solar radiation vapour pressure and wind speed were worked out (Allen et al., 1998). Meteorological data for the simulation studies, Crop and soil data were collected from department of Agrometeorology, IGKV,
Raipur. The CERES-wheat model for the genotype kanchan variety was well calibrated (Table 2) based on field experiment data, soil data and actual weather parameters (i.e. minimum and maximum temperature, rainfall and bright sunshine hours).

Indian Institute of Tropical Management (IITM, Pune) describes future scenarios for the period 2021-2050 referred to as 2030's, 2040's and 2050's respectively. CERESwheat model was used to simulate the growth stages and yield attributes from baseline and projected climate change scenarios under different sowing environments at four stations.

\section{Results and Discussion}

\section{Effect of present and projected climate production of wheat crop}

A study has been carried out to examine the present and projected climate analysis on wheat crop for the year 2030, 2040 and 2050 using dynamic crop simulation model CERES under different dates of sowing in Raipur district of Chhattisgarh. These results are sown in Table 1, 2 and Figure 1, 2, and 3.

\section{Anthesis duration}

Figure 1 shows that the duration of anthesis slightly decreases during present and future climate scenario in all three dates of sowing. At $1^{\text {st }}$ date of sowing (D1) varied from 95 to 91days, $2^{\text {st }}$ date of sowing (D2) 96 to 89 days and $3^{\text {st }}$ date of sowing (D3) 93 to 86 days respectively.

\section{Maturity duration}

Regarding maturity it varies from 130 to 123 days under D1, at D2 it varies from 128 to 121days and D3 124 to 118 days under present and projected scenario (Table 3 ). 
Table.1 Geographical position of representative regions in Chhattisgarh

\begin{tabular}{lcccc}
\hline S. NO. & Station & Latitude & Longitude & Altitude(m) \\
\hline 1 & Raipur & $21^{\circ} 14^{\prime} \mathrm{N}$ & $81^{\circ} 39^{\prime} \mathrm{E}$ & 289 \\
\hline
\end{tabular}

Table.2 Genetic coefficients used for Kanchan variety in CERES-Wheat model

\begin{tabular}{cc}
\hline Parameters & Genetic coefficients \\
P1V & 16.0 \\
P1D & 53.0 \\
P5 & 710.0 \\
G1 & 21.0 \\
G2 & 27.0 \\
G3 & 1.3 \\
PHINT & 60.0 \\
\hline
\end{tabular}

Table.3 Comparison of present and projected climate change scenario of wheat (var. Kanchan) phenological stages under different dates of sowing at Raipur district of Chhattisgarh

\begin{tabular}{|l|l|l|l|l|l|}
\hline Station & $\begin{array}{l}\text { Dates of } \\
\text { sowing }\end{array}$ & $\begin{array}{l}\text { In year } \\
\mathbf{2 0 1 4}\end{array}$ & \multicolumn{1}{l}{$\begin{array}{l}\text { In year } \\
\mathbf{2 0 3 0}\end{array}$} & $\begin{array}{l}\text { In year } \\
\mathbf{2 0 4 0}\end{array}$ & $\begin{array}{l}\text { In year } \\
\mathbf{2 0 5 0}\end{array}$ \\
\hline \multirow{5}{*}{ Days of anthesis } \\
\cline { 2 - 6 } & \multicolumn{5}{|c|}{} \\
\cline { 2 - 6 } & D1 & 95 & 93 & 91 & 91 \\
\cline { 2 - 6 } & D2 & 96 & 91 & 90 & 89 \\
\cline { 2 - 6 } & D3 & 93 & 89 & 87 & 86 \\
\cline { 2 - 6 } & \multicolumn{5}{|c|}{ Days of maturity } \\
\cline { 2 - 6 } & D1 & 130 & 126 & 122 & 121 \\
\cline { 2 - 6 } & D2 & 128 & 124 & 119 & 118 \\
\cline { 2 - 6 } & D3 & 124 & 120 & & \\
\hline
\end{tabular}

Table.4 Comparison of present and projected climate change scenario on vegetative weight and grain weight $(\mathrm{kg} / \mathrm{ha})$ under different dates of sowing at Raipur district of Chhattisgarh

\begin{tabular}{|l|l|l|l|l|l|}
\hline Station & $\begin{array}{l}\text { Dates of } \\
\text { sowing }\end{array}$ & $\begin{array}{l}\text { In year } \\
\mathbf{2 0 1 4}\end{array}$ & $\begin{array}{l}\text { In year } \\
\mathbf{2 0 3 0}\end{array}$ & $\begin{array}{l}\text { In year } \\
\mathbf{2 0 4 0}\end{array}$ & $\begin{array}{l}\text { In year } \\
\mathbf{2 0 5 0}\end{array}$ \\
\hline \multirow{5}{*}{ Raipur } & \multicolumn{5}{|c|}{ Biomass weight (kg/ha) } \\
\cline { 2 - 6 } & D1 & 8963 & 6295 & 5435 & 6257 \\
\cline { 2 - 6 } & D2 & 7786 & 5689 & 4169 & 5664 \\
\cline { 2 - 6 } & D3 & 6978 & 4803 & 3858 & 5374 \\
\cline { 2 - 6 } & \multicolumn{5}{|c|}{ Grain weight (kg/ha) } \\
\cline { 2 - 6 } & D1 & 4358 & 4030 & 3890 & 3497 \\
\cline { 2 - 6 } & D2 & 4300 & 3939 & 3519 & 3345 \\
\cline { 2 - 6 } & D3 & 4046 & 3350 & 3003 & 3122 \\
\hline
\end{tabular}


Fig.1 Effect of climate change on days of anthesis of kanchan variety

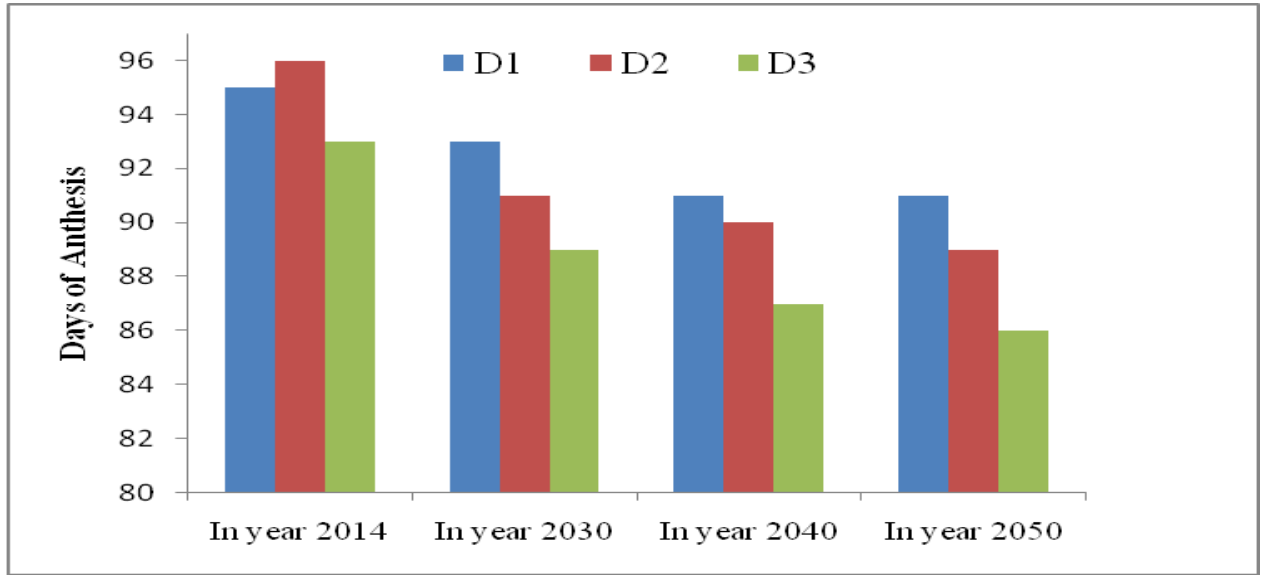

Fig.2 Effect of climate change on days of maturity of kanchan variety

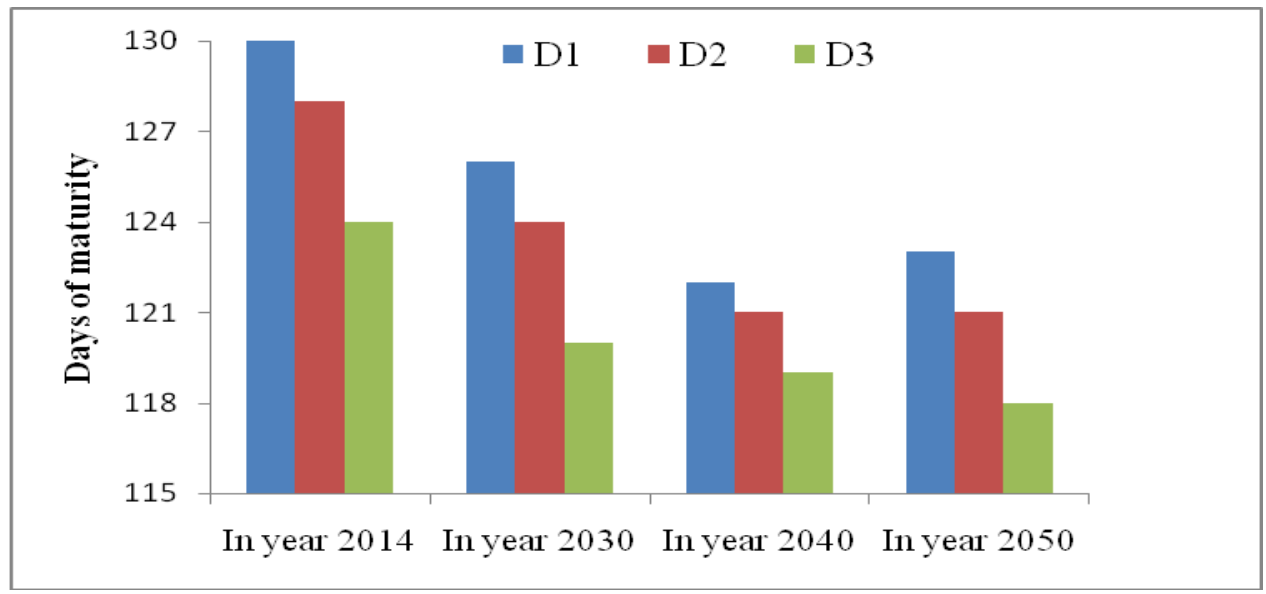

Fig.3 Effect of climate change on biomass yield of kanchan variety

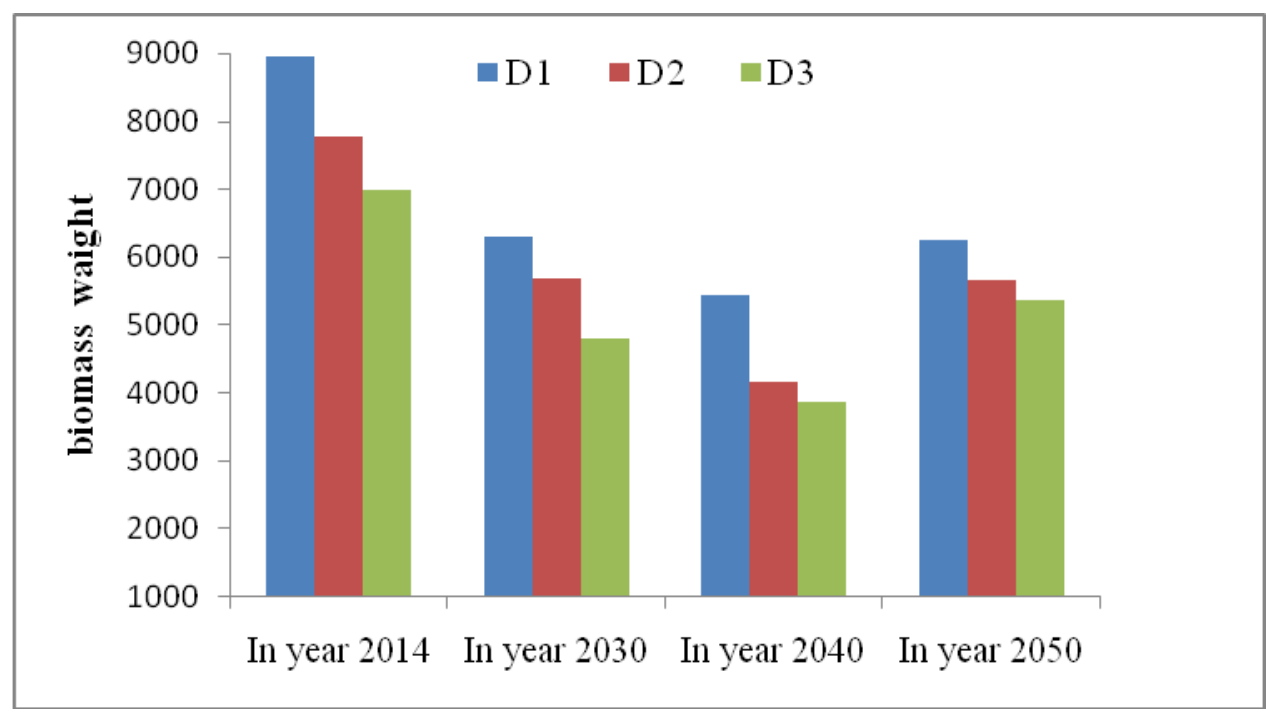


Fig.4 Effect of climate change on grain yield of kanchan variety

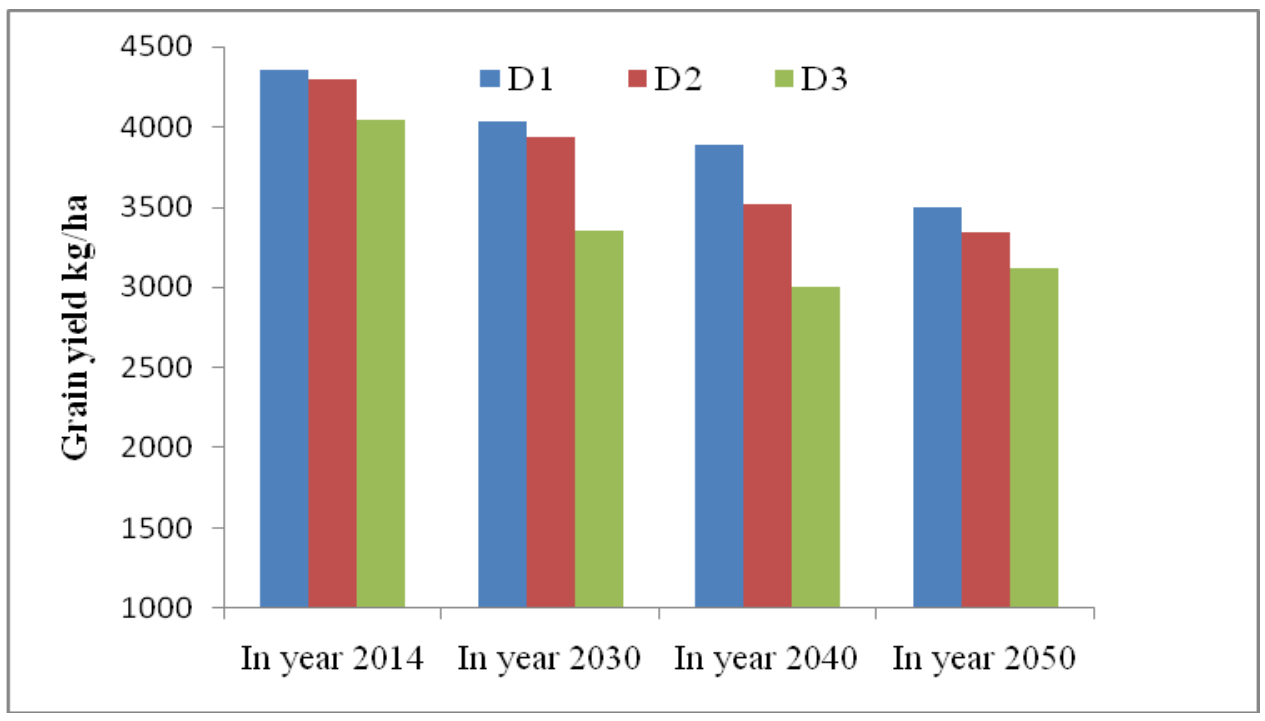

It is interesting at 2040's slightly decrease and again increases in 2050's $1^{\text {st }}$ dates of sowing under present (2014) and future (2030, 2040 and 2050) climatic scenarios.

\section{Biomass production}

The biomass production also decreases considerably in the four climatic scenario at Raipur station. In the total biomass production varied from $89.6 \mathrm{q} / \mathrm{ha}$ to $62.5 \mathrm{q} / \mathrm{ha}$ in $\mathrm{D} 1$ condition, while D2 varied from $77.8 \mathrm{q} / \mathrm{ha}$ to $56.6 \mathrm{q} / \mathrm{ha}$ and D3 condition it varied from $69.7 \mathrm{q} / \mathrm{ha}$ under present scenario to $53.7 \mathrm{q} / \mathrm{ha}$ the different three projected scenario. It is interesting to the total biomass production in the year 2040 decreases more than the year 2050 and from all three projected scenario slightly increases biomass production at 2050's at all three dates of sowing. Highest reduction was noticed in 2040 year under three dates of sowing.

\section{Grain yield}

The grain yield also decreases in the four different climate scenario and different dates of sowing. In Raipur the present climate scenario the production of wheat yield 43.5 $\mathrm{q} / \mathrm{ha}$ and decreases to $40.3,38.9,34.9 \mathrm{q} / \mathrm{ha}$ under the climate scenario of 2030, 2040 and 2050 in D1. D2 varies from $43.0 \mathrm{q} / \mathrm{h}$ a to 33.4 q/ha. In D3 40.4 q/ha to 31.2 q/ha. Highest grain yield was found in 2030's followed by 2040's and 2050's in future scenarios at all dates of sowing under present scenario. Highest grain yield lost at 2040's in D3 date of sowing (Fig. 4 and Table 4).

There is negative impact on crop production potential in different three dates of sowing at Raipur District of Chhattisgarh. Know it is clear that from analysis the Production of wheat is very low at 2040 's climate scenario and $3^{\text {rd }}$ date of sowing also, hence a substitute for work out in coming year. 2050's is still is favourable for wheat crop even under change climate scenario under all three date of sowing. It is necessary to develop suitable technologies for increasing the productivity levels of crops under climate changing scenario.

\section{Acknowledgement}

The first author is thankful to staff of department of Agrometeorology, College of Agriculture, Indira Gandhi Krishi 
Vishwavidhyalaya Raipur, Chhattisgarh for their precious guidance and support for carrying out research. And also would like to express special gratitude to Dr. A.S.R.A.S. Sastri (Former professor, Agrometeorology, IGKV, Raipur) for his constant support and valuable advice throughout the research.

\section{References}

Allen, R. G., Pereira, L. S., Raes, D., Smith, M. (1998). FAO Irrigation and drainage paper No.56, Crop evapotranspiration: guidelines for computing crop water requirements. FAO. Rome, Italy.

Asseng, S., Foster, I. and Turner, N.C. (2011). The impact of temperature variability on wheat yields. Global Change Biology, 17: 997-1012.

Chhabra, V. and Haris, A.A. (2014). Temperature Trends and their impact on rabi crops in changing climatic scenario of Bihar. Sch J Agric Vet Sci., 1(4A): 230-234.

IPCC (2007). Climate Change 2007. The
Physical Science Basis. In: Contribution of Working Group I to the Fourth Assessment Report of the Intergovernmental Panel on Climate Change. Solomon, S., D. Qin, M. Manning, Z. Chen, M. Marquis, K.B. Averyt, M.

Mearns, L.O. (2000). Climatic change and variability. In: Reddy KR, Hodges HF (Eds.) Climate change and global crop productivity. CABI Publishing, Wallingford, p 7-35.

Modarresi, M., Mohammadi, V., Zali, A. and Mardi, M. (2010). Response of Wheat Yield and Related Traits to High Temperature. Cereal Research Communications. 38(1): 23-31.

Sastri, A. S. R. A. S. (2010). Climate Change in Indian Sub-Continent and its impact on Agriculture. Nova Acta Leopoldina. 384: 227-240.

Singh, V. and Dev, P. (2012). 50 year rainfall data analysis and future trend in Saharanpur region. Mausam. 63(1): 5564.

\section{How to cite this article:}

Beck, M.K., A. Jain and Mohanty, S. 2017. Assessing Production Potential of Wheat Crop (Var; Kanchan) in Raipur District of Chhattisgarh Region under Projected Climate Scenarios. Int.J.Curr.Microbiol.App.Sci. 6(12): 2480-2485. doi: https://doi.org/10.20546/ijcmas.2017.612.288 